Revista Brasileira de Meteorologia, v.25, n.4, 427 - 436, 2010

\title{
ANALYSIS OF THE EVAPORATIVE FRACTION USING EDDY COVARIANCE AND REMOTE SENSING TECHNIQUES
}

\section{CARLOS ANTONIO COSTA DOS SANTOS, BERNARDO BARBOSA DA SILVA AND TANTRAVAHI VENKATA RAMANA RAO}

Unidade Acadêmica de Ciências Atmosféricas, Universidade Federal de Campina Grande, Campina Grande - UFCG, PB, Brasil.

carlostorm@gmail.com, bernardo@dca.ufcg.edu.br, ramanarao_tantravahi@yahoo.com.br

Received October 2009 - Accepted March 2010

\begin{abstract}
The main objective of this study was to demonstrate the ability of the instantaneous measurements of the evaporative fraction (EF) to estimate the average daily EF and apply the remote sensing algorithm (SEBAL - Surface Energy Balance Algorithms for Land) to obtain the regional distribution of the instantaneous EF in the Semi-arid region of Brazil. The results show that cloudiness is not related to stability of EF and that the correlation between the diurnal stability of EF and the meteorological parameters have shown weak correlation on cloudy days, and strong correlation with the vapor pressure deficit (VPD) on cloud free days. The EF derived from remote sensing data were compared with the field measurements and presented absolute percent difference less than $12 \%$, evidencing the agreement between the SEBAL algorithm results and measured data, and showing that it is a promising tool to provide estimates of the EF to obtain the evapotranspiration.
\end{abstract}

Keywords: Evapotranspiration, banana crop, semi-arid, SEBAL.

RESUMO: ANÁLISES DA FRAÇÃO EVAPORATIVA USANDO AS TÉCNICAS DAS CORRELAÇÕES TURBULENTAS E SENSORIAMENTO REMOTO

O principal objetivo desse estudo é demonstrar a capacidade de utilizar medidas instantâneas da fração evaporativa (FE), para estimar a FE média diária e aplicar o algoritmo de sensoriamento remoto (SEBAL - Surface Energy Balance Algorithms for Land), e para obter a distribuição regional da FE instantânea na região Semi-árida do Brasil. Os resultados mostraram que a nebulosidade não está relacionada com a estabilidade da FE, e que a correlação entre a estabilidade diurna da FE e os parâmetros meteorológicos tem mostrado fraca correlação em dias nublados, assim como forte correlação com o déficit de pressão do vapor (DPV) em dias de céu claro. As FEs derivadas de dados de sensoriamento remoto foram comparadas com medidas de campo e apresentaram diferença percentual absoluta menor que $12 \%$, evidenciando a concordância entre os resultados do algoritmo SEBAL e os dados medidos, mostrando que é uma ferramenta promissora para prover estimativas da FE para obter a evapotranspiração.

Palavras-chave: Evapotranspiração, banana, semi-árido, SEBAL. 


\section{INTRODUCTION}

Estimates of evapotranspiration (ET) are of crucial importance for climatic studies, weather forecasts, ecological monitoring, hydrological surveys, and water resource management (Bastiaanssen et al., 2000). Within the semi-arid agricultural regions, where hydrological cycle is strongly influenced by ET through crop water consumption, a precise ET estimation is necessary for water use efficiency (Hoedjes et al., 2008). However, in practice, continuous daily ET measurements are rarely available (Farah et al., 2004). More recently, one or more instantaneous measurements of ET have been used to estimate daily total ET (Brutsaert and Sugita, 1992). There has been a growing interest in this approach because of its importance for remote sensing applications (Farah et al., 2004). Remote sensing techniques offer means of estimating actual ET at a large spatial scale, which is not possible with the traditional point methods.

The fundamental problem in using remote sensing techniques to estimate the ET in local and regional scales is the scaling of instantaneous latent heat flux (LE) to daily ET, because remotely sensed data, in general, are provided by satellite or airborne platforms (Colaizzi et al., 2006). Chávez et al. (2008) explain that in the use of satellite imagery there are other important things to consider, such as the spatial resolution, overpass frequency, cloud cover presence at overpass time, etc., which sometimes limits the application. Airborne platforms are capable flying on cloud free days and at different elevations, is a valuable tool for mapping ET at very high resolution on a near daily basis (Chávez et al., 2008). Many techniques have been proposed to solve the surface energy balance from remote sensing (Kustas and Norman, 1996; Bastiaanssen et al., 1998; Roerink et al., 2000). However, remote sensing data are instantaneous measurements and a method is required to temporally integrate instantaneous estimates of ET.

The components of the energy balance display considerable diurnal variation over land surfaces (Farah et al., 2004). However, several ratios of the fluxes have been shown to be relatively constant during daylight hours (Shuttleworth et al., 1989; Bastiaanssen et al., 1998; Gentine et al., 2007). More recently the evaporative fraction (EF) has been found to have a little variation during daytime, although it is directly related to Bowen ratio ( $\beta$ ) (Crago and Brutsaert, 1996), the diurnal behavior of EF can be understood from its relationship with atmospheric conditions and surface characteristics. The evaporative fraction is defined as:

$$
E F=\frac{L E}{R_{n}-G}=\frac{L E}{L E+H}=\frac{1}{1+\beta}
$$

where $L E$ is the latent heat flux, $R_{n}$ is the net radiation, $H$ is the sensible heat flux, and $G$ is the soil heat flux.

The first paper that noticed the constancy of EF, during daylight hours, was by Shuttleworth et al. (1989). They analyzed data of 4 clear sky days over relatively homogeneous grasslands and found that the midday EF is nearly equal to the average daylight. Nichols and Cuenca (1993), using 72 days data, showed that the midday EF was highly correlated with average daytime EF, but that the midday and daytime $\mathrm{EF}$ are not equal (Farah et al., 2004). Crago (1996a) used the data irrespective of weather conditions of a particular day and concluded that midday EF is significantly different from the average daytime value, the reason being the concave-up shape of the diurnal progression of EF. Crago (1996b) affirms that under clear sky days, the steadiness and predictability of the daytime cycle of radiation, heat, and humidity tend to cause the components of the energy balance to vary rather slowly.

In addition, some simple ratios of energy balance components, principally the $\mathrm{EF}$, tend to have little variation during the daytime. As cloud fields tend to be heterogeneous, the available energy and rate of surface heating tend to fluctuate erratically during the day under varying cloud cover, leading to changes in the EF. Crago (1996b) still affirms that the atmosphere is linked in a very complicated way to the land surface, and a simple concept such as the conservation of the $\mathrm{EF}$ is a convenient tool, rather than a physical principle. The variability of $\mathrm{EF}$ is in fact due to a complex interaction of radiative and cloud effects, and various feedback relationships between land surface variables and atmospheric variables. Crago (1996b) affirmed that the constant EF hypothesis is surprisingly robust. However, varying cloud conditions and proximity to surface discontinuities or fronts may cause significant change in the EF. In practice, remote sensing may help identify these conditions (Crago 1996b; Chávez et al., 2008).

The purpose of this paper is to: 1) demonstrate the ability of the instantaneous measurements of $\mathrm{EF}$ to estimate the average daily EF in the semi-arid region of Brazil, and 2) apply the remote sensing algorithm (SEBAL) to estimate the regional distribution of the instantaneous EF using the combination of Landsat 5 - TM observations and ground-based data by eddy covariance measurements to validate the results.

\section{MATERIAL AND METHODS}

\subsection{Site Description}

The study area was located in the irrigation district of Quixeré in Low Jaguaribe basin, Ceará/Brazil. The instruments were installed in the Frutacor farm, with an approximate area of 250 ha of banana crop (Musa sp.) located at $5^{\circ} 08^{\prime} 44^{\prime \prime}$, 
$38^{\circ} 05^{\prime} 53^{\prime \prime} \mathrm{W}$ and an elevation of $147.0 \mathrm{~m}$, approximately. The referred area is illustrated in the Figure 1. The spacing between rows and plants was $4.0 \mathrm{~m}$ and $2.4 \mathrm{~m}$, respectively. The plant height was approximately $5.0 \mathrm{~m}$, and the crop is irrigated by subsurface drip irrigation. The area presents semi-arid climate, type BSw'h', according to the Köeppen's classification. Mean annual temperature is $28.5^{\circ} \mathrm{C}$, with the maximum and minimum annual temperatures of $36^{\circ} \mathrm{C}$ and $22^{\circ} \mathrm{C}$, respectively. The mean annual precipitation is $772 \mathrm{~mm}$, based on monthly mean distribution for 25 years (1981 - 2006) registered at the Quixeré weather station; it is presented in Figure 2 and the mean annual relative humidity is $62 \%$.

\subsection{Data and Methods}

The data was collected during the period of October/2005 to September/2006, due instrumental and electrical problems the number of days used in this study is 142 . The climatic data was provided by an automatic weather station (106 Weather Station, Campbell Scientific Inc., Logan, UT, USA) (Figure 3); these data were used to obtain the reference evapotranspiration $\left(E T_{o}\right)$ by combined FAO - Penman-Monteith method (Allen et al., 1998). The net radiation $\left(R_{n}\right)$ was computed using the four components (Equation 2) and acquired with a net radiometer (model CNR1, Kipp \& Zonnen, Delf, Netherlands) installed at $7.0 \mathrm{~m}$ above the ground level and $2.0 \mathrm{~m}$ above the crop canopy in the rows (Table 1). The soil heat flux $(G)$ was measured with two heat flux plates (model HFP01SC-L, Campbell Scientific, Inc., Logan, UT) at $2.0 \mathrm{~cm}$ depth (Table 1). Flux plates were buried one between rows and the other between plants, because the remote sensing techniques have been used to obtain the spatial scale of the energy balance components. Thus, the values of the $\mathrm{G}$ were obtained as the average of the two measurements to represent different conditions inside the pixel. The $R_{n}$ is given by the expression:

Table 1 - The instruments of eddy covariance system and weather station

\begin{tabular}{llll}
\hline & Variables & Instruments & Heights \\
\hline Eddy covariance system & Wind speed & CSAT3 3D sonic anemometer & $7.0 \mathrm{~m}$ \\
& Air temperature humidity & HMP45C probe & $7.0 \mathrm{~m}$ \\
& $\mathrm{CO}_{2} / \mathrm{H}_{2} \mathrm{O}$ analyzer & Licor 7500 & $7.0 \mathrm{~m}$ \\
& Soil heat flux & HFP01SC-L & $-2.0 \mathrm{~cm}$ \\
Weather station & Reference ET & T. Weather 106 Weather Station & $2.0 \mathrm{~m}$ \\
\hline
\end{tabular}

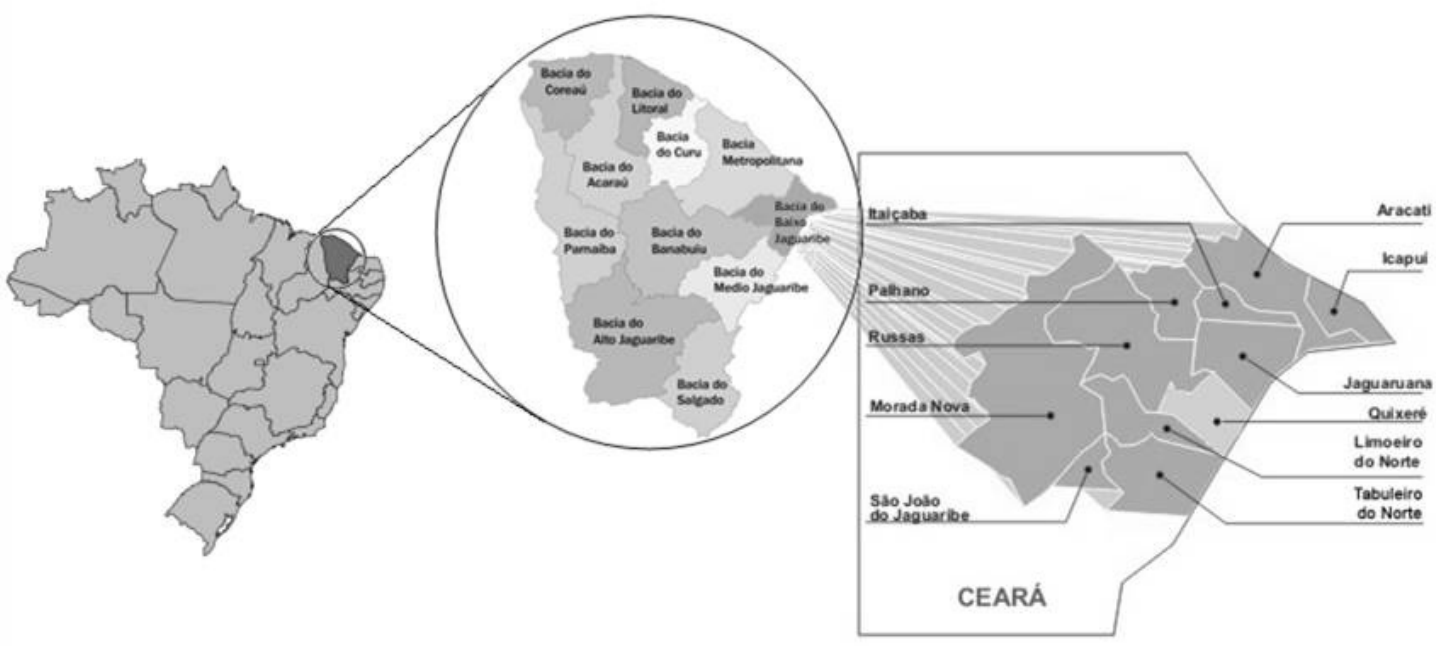

Figure 1 - Location of the Low Jaguaribe basin and the irrigation district of Quixeré. 


$$
R_{n}=S_{\text {solar }}-S_{\text {ref }}+L_{\text {atm }}-L_{\text {surface }}
$$

where $S_{\text {solar }}$ is the global solar radiation, $S_{\text {ref }}$ is the reflected solar radiation flux, $L_{\text {atm }}$ is the incoming longwave radiation flux and $L_{\text {surface }}$ is the outgoing long-wave radiation flux (Tanaka et al., 2008). The air temperature and relative humidity were measured using a Vaisala HMP45C probe.

To obtain the turbulent flux measurements, the eddy covariance (EC) system, composed of a fast-response open-path infrared gas analyzer (model LI-7500, Licor, Inc., Lincoln, NE) to measure $\mathrm{CO}_{2}$ and $\mathrm{H}_{2} \mathrm{O}$, coupled with a three-dimensional sonic anemometer (model CSAT-3, Campbell Scientific, Inc., Logan, UT), used to measure wind speed component fluctuations, were installed at $7.0 \mathrm{~m}$ above ground level (Figure 4) (Table 1). Digital signals from these instruments were recorded at $10 \mathrm{~Hz}$ and the averages were obtained at 30 minute intervals using a Campbell Scientific CR23X datalloger, where the data were stored for later processing (Figure 4).

Giolia et al. (2004) affirm that this technique provides a unique opportunity to measure the surface energy fluxes directly. The use of this technique is problematic when the gradient of the specific humidity, and thus the latent heat flux, is very small (Kalthoff et al., 2006). The EC technique measures the turbulent fluxes by measuring the fluctuations around a long-term mean, and the sensible heat flux has been calculated according the following equation (Twine et al., 2000):

$$
H=\rho_{\text {air }} c_{p} \overline{w^{\prime} T^{\prime}}
$$

and the latent heat flux using the equation:

$$
L E=\rho_{\text {air }} c_{p} \overline{w^{\prime} q^{\prime}}
$$

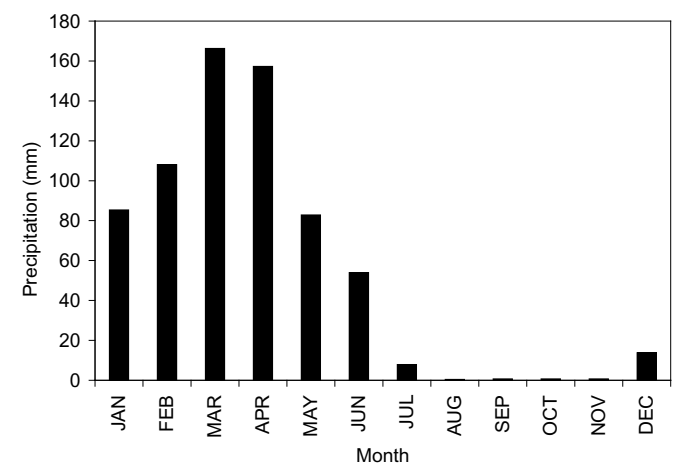

Figure 2 - Distribution of the monthly averages of the precipitation in Quixeré (1981 - 2006). where the overbar in the Eqs. (3) and (4) denotes the time average, in general, of $30 \mathrm{~min}, \rho$ is the air density $\left(\mathrm{kg} \mathrm{m}^{-3}\right), w^{\prime}$ the vertical wind speed fluctuation $\left(\mathrm{m} \mathrm{s}^{-1}\right)$, $T^{\prime}$ the air temperature fluctuation $\left({ }^{\circ} \mathrm{C}\right), q^{\prime}$ the specific humidity fluctuation (deviations from the time average), and $L$ is the latent heat of water $\left(2.508 \times 10^{6} \mathrm{~J} \mathrm{~kg}^{-1}\right)$.

To analyze the diurnal stability of EF, the standard deviation of measured EF, between 7:00 and 17:00 h, was obtained using the Equation 1. Farah et al (2004) analyzed the relationship between the standard deviation of EF and air temperature, relative humidity and the degree of cloudiness to see if routinely collected weather station data could be used to understand the diurnal stability of EF. The degree of cloudiness is more accurately expressed as a shortwave transmittance $(\tau)$ (Farah et al., 2004):

$$
\tau=\frac{S \downarrow}{S \downarrow_{T O A}}
$$

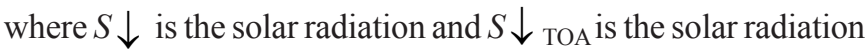
on the top of the atmosphere which can be obtained based on standard astronomical equations. To examine the effect of cloudiness on the stability of EF, the daily average $\tau$ values were divided into three groups: cloudy $(\tau<0.5)$, partly cloudy $(0.5<\tau<0.65)$ and clear $(\tau>0.65)$ as defined in Farah et al. (2004). Table 2 shows the behavior of the minimum, maximum and average of standard deviation of EF for the three groups.

In this research, the relationship between the morning EF (9:00 - 10:00) and daytime EF (7:00 - 17:00) (because the time 9:00-10:00 is the Landsat 5 satellite overpass in the study area) and the relationship between midday EF (12:00 - 13:00, local time) and daytime EF were analyzed to evidence the daily behavior of EF.

In the application of the remote sensing algorithm (SEBAL), 3 images from TM Landsat 5 satellite (10/24/2005,

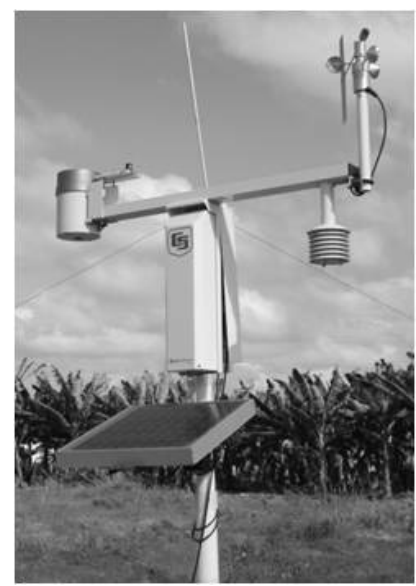

Figure 3 - Automatic weather station (ET106) installed within the study area of the banana orchard, located in Frutacor farm, Quixeré/Brazil. 
$01 / 28 / 2006$ and $08 / 24 / 2006$ ) with a total area of $44,478.5$ ha, referring to the path 216 and row 64 were used. These images have been used to process the intermediate parameters from which surface energy flux components were estimated. In this paper only three images covering the entire period were used for the analyses. As the study area is located close to the equatorial region, which presents a persistent cloud cover, very few cloud free images have been available.

\subsubsection{Remote Sensing Algorithm}

Surface energy fluxes require energy inputs, moisture conditions of soil and vegetation and surface microclimate conditions (French et al., 2000; Melesse and Nangia, 2005). Remote sensing has proven to provide the energy inputs through the shortwave and longwave radiation and surface moisture conditions of soil and vegetation at reasonable spatial and temporal scales (Melesse and Nangia, 2005). The surface microclimate can be obtained from the long-term meteorological observations.

The surface energy budget satisfying the law of conservation of energy in the absence of horizontally advective energy can be expressed as:

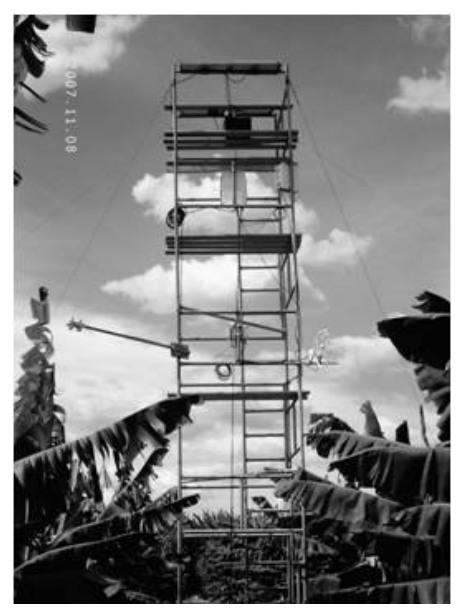

Figure 4 - Eddy covariance tower installed within the study area of the banana orchard, located in Frutacor farm, Quixeré/Brazil.

$$
R_{n}=H+L E+G
$$

The Surface Energy Balance Algorithms for Land (SEBAL) (Bastiaanssen et al., 1998) model utilizes remotely sensed data to solve the Equation 6 by computing surface energy fluxes from satellite images and weather data. Application details are given in Bastiaanssen et al. (1998). The computation of $R_{n}$ for each pixel uses albedo and transmittances obtained from shortwave bands and longwave emission computed from the thermal band. The $G$ in these algorithms is determined through semi-empirical relationships with $R_{n}$, surface albedo, surface temperature, and vegetation index (Bastiaanssen et al., 1998; Bastiaanssen et al., 2000; Compaoré et al., 2008; Teixeira et al., 2009a,b):

$$
G=\frac{T-273.16}{\alpha}\left(0.0038 \alpha+0.0074 \alpha^{2}\right)\left(1-0.98 N D V I^{4}\right) R_{n}
$$

where $N D V I$ is the Normalized Difference Vegetation Index computed from red and NIR bands, $T(\mathrm{~K})$ is radiometric surface temperature computed from the thermal band using a modified Planck equation, and $\alpha$ is the surface albedo.

The obtaining of $H$ through of SEBAL algorithm needs measurements of the wind speed at a known height and surface temperature pixel by pixel using an internal calibration of temperature difference of the air near the surface as described by Bastiaanssen et al. (1998) and Tasumi et al. (2005):

$$
H=\frac{\rho_{a i r} c_{p}\left(a+b T_{s}\right)}{r_{a h}}
$$

where $\rho_{\text {air }}$ is the humid air density $\left(\mathrm{Kg} \mathrm{m}^{-3}\right), c_{p}$ is the specific heat of dry air at constant pressure $\left(1005 \mathrm{Jkg}^{-1} \mathrm{~K}^{-1}\right), r_{a h}$ is the aerodynamic resistance to heat transport $\left(\mathrm{s} \mathrm{m}^{-1}\right), T_{s}$ is the surface temperature (K) and $a$ and $b$ are empirical calibration coefficients obtained for each image. The term $\left(a+b T_{s}\right)$ (Bastiaanssen et al., 1998) presented in Equation 8 is the temperature difference close to the surface calculated between the 0.1 and $2.0 \mathrm{~m}$ heights. The definitions of $a$ and $b$ coefficients require choice of two pixels, representing the extreme conditions of temperature and

Table 2 - Mean daytime and mean daytime standard deviation values of EF selected according to shortwave transmittance $(\tau)$ in order to understand the correlation between cloudiness and diurnal stability of EF

\begin{tabular}{cccccc}
\hline $\begin{array}{c}\text { Number of } \\
\text { days }\end{array}$ & Transmittance & Mean EF & $\begin{array}{c}\text { Mean standard } \\
\text { deviation of EF }\end{array}$ & $\begin{array}{c}\text { Maximum } \\
\text { value of EF }\end{array}$ & $\begin{array}{c}\text { Minimum } \\
\text { value of EF }\end{array}$ \\
\hline 26 & $\tau<0.50$ & 0,63 & 0.086 & 0.122 & 0.054 \\
97 & $0.50 \leq \tau \leq 0.65$ & 0.59 & 0.088 & 0.153 & 0.039 \\
19 & $\tau>0.65$ & 0,56 & 0.076 & 0.108 & 0.044 \\
\hline
\end{tabular}


humidity, called the hot and cold pixels, where the temperature difference $(d T)$ was calculated using the known values of $H$ for these cited pixels.

For the cold pixel, chosen over an irrigated area, $H$ is assumed to be zero and, consequently $d T=0$ and $L E=R_{n}-G$. The hot pixel was chosen over an area of bare soil, where $L E=$ 0 and the $H$ value is calculated from the difference $H=R_{n}-G$ and $d T=H r_{a h} / \rho_{a i r} c_{p}$. The initial values of $\mathrm{H}$ do not represent adequately the real value of $H$ for each pixel and serve only as the initial parameters of an iterative process (Bastiaanssen et al., 1998), in which the stability conditions are considered for each pixel. To correct the buoyancy effect the similarity theory of Monin-Obukhov, based in Monin-Obukhov length $(L)$, is applied and is presented in the following equation:

$$
L=-\frac{\rho_{a i r} c_{p} u_{*}^{3} T_{s}}{k g H}
$$

where $u *$ is the friction velocity $\left(\mathrm{m} \mathrm{s}^{-1}\right), k$ is the von Karman constant and $g$ is the acceleration due to gravity $\left(9.81 \mathrm{~m} \mathrm{~s}^{-2}\right)$, pixel by pixel, obtained initially considering a neutral stability condition.

To identify the stability conditions it is necessary to analyze the $L$ values which are given as follows: if $L<0$, the atmosphere is considered to be unstable; if $L=0$ is considered neutral; and $L>$ 0 is considered stable. Depending on the atmospheric conditions, the values of the stability corrections, for the momentum transport $\left(\psi_{m}\right)$ and the heat transport $\left(\psi_{h}\right)$ must be considered as given in Bastiaanssen et al. (1998). When the final sensible heat flux is obtained, the $L E$ is determined by solving the Equation 6 . The detailed technique for estimating latent and sensible heat fluxes using remote sensing has been documented and tested in different parts of the world, such as Europe, Asia, Africa, and Idaho in the USA and proved to provide good results (Bastiaanssen et al., 1998; Bastiaanssen et al, 2000; Melesse and Nangia, 2005; Melesse et al., 2008).

In summary, the latent heat flux describes the amount of energy required to maintain a certain crop evapotranspiration rate. Surface albedo, surface temperature and vegetation index are derived from satellite measurements and are used together to solve $R_{n}, G$ and $H$. Surface temperature is an important parameter for the computation of the sensible heat flux, $H$. The latent heat flux, $L E$, is the residual term and is used to compute the instantaneous evaporative fraction $\left(E F_{\text {inst }}\right)$ :

$$
E F_{\text {inst }}=\frac{L E_{\text {inst }}}{R_{n_{-} \text {inst }}-G_{\text {inst }}}
$$

The instantaneous $E F$ is an expression to obtain the evapotranspiration when the atmospheric moisture conditions are in equilibrium with the soil moisture conditions (Bastiaanssen et al., 1998). As the evaporative fraction is temporally constant, the difference between instantaneous EF at the moment of satellite overpass and the EF derived from the 24-hour integrated energy balance is marginal, and may be neglected.

\section{RESULTS AND DISCUSSION}

Studies have shown that evaporative fraction $(\mathrm{EF})$ is often nearly constant during the daytime. In this study the standard deviation of measured EF between 7:00 and 17:00h was used as an indicator of the diurnal stability of EF. The mean standard deviation during the study period is 0.088 at an average EF of 0.64 showing a coefficient of variation of 0.10 . The standard deviation varied between a minimum value of 0.036 and a maximum value of 0.088 .

To examine the effect of cloudiness on the stability of EF, the days were stratified according to the daily average shortwave transmittance in three groups. The groups have been defined as cloudy $(\tau<0.50)$, partly cloudy $(0.50>\tau<$ $0.65)$ and clear $(\tau>0.65)$. Table 2 shows the analysis of the correlation between standard deviation of $\mathrm{EF}$ and the degree of cloudiness. It is possible to identify that the mean EF and mean standard deviation of EF for the three groups are almost the same, indicating that cloudiness is not related to stability of EF, evidencing the results found in Farah et al. (2004). The effect of clouds on the diurnal cycle of EF has been studied by several researchers. Sugita and Brutsaert (1992) affirm that daytime changes in EF are due to changes in cloudiness. Hall et al (1992) showed that variations in net radiation due to cloudiness do not affect significantly EF. These disagreements between studies show that diurnal variability of EF is a complex phenomenon and other factors may exert influence on the variations of EF which needs a careful analysis. The number of days to the different groups, the mean standard deviation, and the maximum and minimum values of EF are shown in Table 2. It is possible to identify that only 19 days were classified as clear days which shows the problem of obtaining the cloud free satellite images in the equatorial region.

An analysis of the relationship between the standard deviation of EF and atmospheric conditions and surface characteristics was undertaken to identify if routinely collected weather data could be used to understand the diurnal stability of EF. Table 3 shows the correlation coefficients (r) between the diurnal stability of EF and the meteorological parameters involved. These correlations have been modeled using polynomial curves of order 2 . The daily standard deviations of EF showed weak correlation with the meteorological parameters on cloudy days, presenting $r$ values equal or lower than 0.30 . On cloud free days the results have presented higher values. The available energy, relative humidity and vapor 
pressure deficit (VPD) showed $r$ values of $0.51,0.52$ and 0.81 , respectively. It evidences that VPD has the best correlation with the diurnal stability of EF in comparison with other meteorological parameters. Thus, the stability of the diurnal cycle of EF on cloudy days can not be adequately explained by micrometeorological state variables only, while the VPD explain $80 \%$ on cloudy free days.

The correlation between morning EF (9:00 - 10:00 h), midday EF (12:00 - 13:00 h) and average daytime EF (7:00 17:00 h) are presented in Figures 5 and 6, respectively. The time series of micrometeorological data, i.e. 142 days, were used to obtain these results. There is a moderate correlation between morning EF and daily EF $(r=0.75)$ and a strong correlation between midday EF and daily EF $(r=0.82)$. The root mean square errors (RMSE) are 0.06 and 0.05 for morning EF and midday EF, respectively. The implication of these results for remote sensing applications is that it is indifferent to obtain the EF from satellites that have morning (between 09:00 and 10:00 h) overpass (for example, TM - Landsat 5 or MODIS - Terra) or afternoon (between 13:00 and 14:00 h) overpass (for example, AVHRR - NOAA and Aqua - MODIS) because the results were not very much different for the studied area. This result evidences that the EF is relatively constant during the daytime hours.

The pattern of the seasonal variation of daytime EF is presented in Figure 7. Each of the points represents the average value of $\mathrm{EF}$ between 7:00 and 17:00 $\mathrm{h}$. The seasonal variation of EF is a reflection of the climate of the area. The EF varied between 0.50 and 0.90 , and these values do not present high variability showing the constant behavior of EF in the studied semi-arid region. The seasonal variation of EF is a consequence of the climatic variables like rainfall and soil moisture. There is an increase in the EF values and in its variability in the beginning of 2006 (Figure 7) in response to the rainfall events, while during the dry season (between the days of year $267 \mathrm{e}$ 345 ) the values stayed between 0.50 and 0.70 . It is possible to identify that the seasonal progression of EF is gradual. Thus, the implication of this for the monitoring of EF is that it would be sufficient to measure EF in every 5-10 days to

Table 3 - Correlation between the daytime standard deviation of EF and meteorological parameters used to explain the diurnal stability of EF on cloudy (123 days) and cloud free (19 days) days.

\begin{tabular}{lcc}
\hline \multicolumn{1}{c}{ Meteorological parameters } & $\mathbf{r}$ (cloudy days) & $\mathbf{r}$ (cloud free days) \\
\hline Air temperature & 0.22 & 0.28 \\
Relative humidity & 0.30 & 0.52 \\
Wind speed & 0.17 & 0.40 \\
Available energy $\left(\mathrm{R}_{\mathrm{n}}-\mathrm{G}\right)$ & 0.17 & 0.51 \\
Transmittance & 0.10 & 0.20 \\
VPD & 0.30 & 0.81 \\
\hline
\end{tabular}

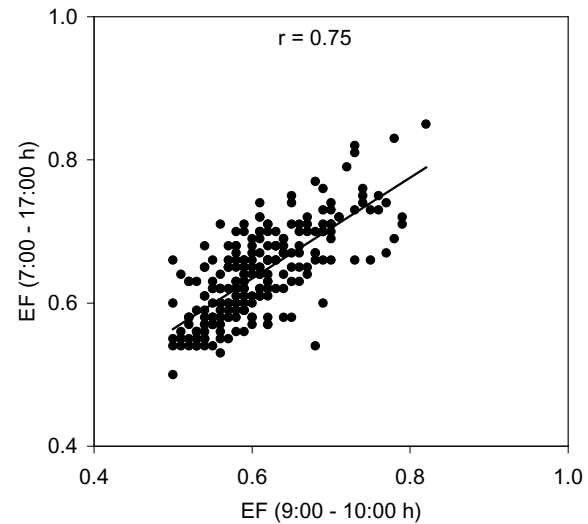

Figure 5 - Correlations between daytime EF and morning EF for the studied period (142 days).

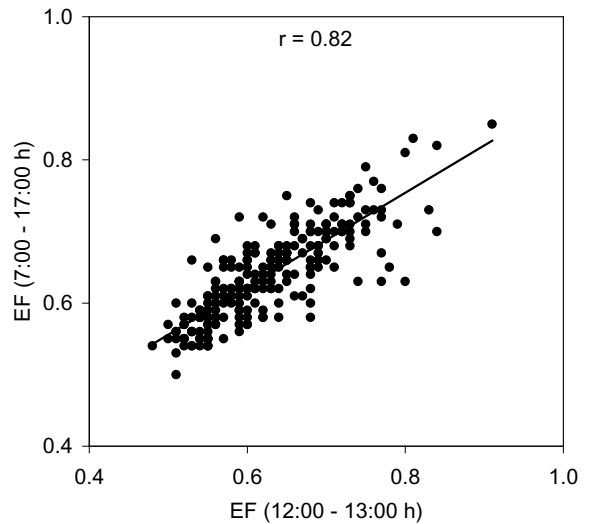

Figure 6 - Correlations between daytime EF and midday EF for the studied period (142 days). 
capture the seasonal evolution of EF. Interpolation between the measurements can be done to estimate EF on days when there are no EF measurements as proposed by Farah et al. (2004) and Teixeira et al. (2009b). This result means that for remote sensing programs processing of daily images is not necessary to estimate the seasonal variations of EF, although daily acquisition may be required to select the qualitative best cloud free images for a given period.

The only available way to obtain ET mapping is to rely on remote sensing data that now have both nearly continuous spatial coverage and adequate temporal sampling using different satellite or geostationary platforms. Different remote sensing-based methods have been developed to estimate ET using either empirical or physically based methods. Physically based methods solve the energy balance at the land surface. Often diurnal self-preservation of EF is used to make the retrieval problem well-posed. Figures 8,9 and 10 show the spatial distribution of EF over the heterogeneous surface of the semi-arid region obtained by remote sensing algorithm (SEBAL) for the days 10/24/2005, 01/28/2006 and 08/24/2006, respectively.

The derived evaporative fractions in the three images over the study area are in good accordance with the land surface. These images cover the irrigated area and native vegetation (Caatinga) with emphasis to banana orchard (experimental site). It is possible to identify in these figures, the irrigated areas like center pivot and rectangular plots with higher values of $\mathrm{EF}$, native vegetation presenting medium values of EF, and bare soil showing lower values of EF. The evaporative fractions derived from Landsat 5 - TM data were compared with the field measurements, as presented in Table 4. The derived EF in the three different images over the study area showed good agreement with the measured data. The images for the days 10/24/2005, 01/28/2006 and 08/24/2006 presented absolute percent difference in comparison with the measured values of $11.0,3.0$ and $3.3 \%$, respectively. These

Table 4 - Comparison between measured EF by eddy covariance technique and estimated EF using remote sensing algorithm (SEBAL) to banana orchard

\begin{tabular}{lcc}
\hline \multicolumn{1}{c}{ Meteorological parameters } & $\mathbf{r}$ (cloudy days) & $\mathbf{r}$ (cloud free days) \\
\hline Air temperature & 0.22 & 0.28 \\
Relative humidity & 0.30 & 0.52 \\
Wind speed & 0.17 & 0.40 \\
Available energy $\left(\mathrm{R}_{\mathrm{n}}-\mathrm{G}\right)$ & 0.17 & 0.51 \\
Transmittance & 0.10 & 0.20 \\
VPD & 0.30 & 0.81 \\
\hline
\end{tabular}

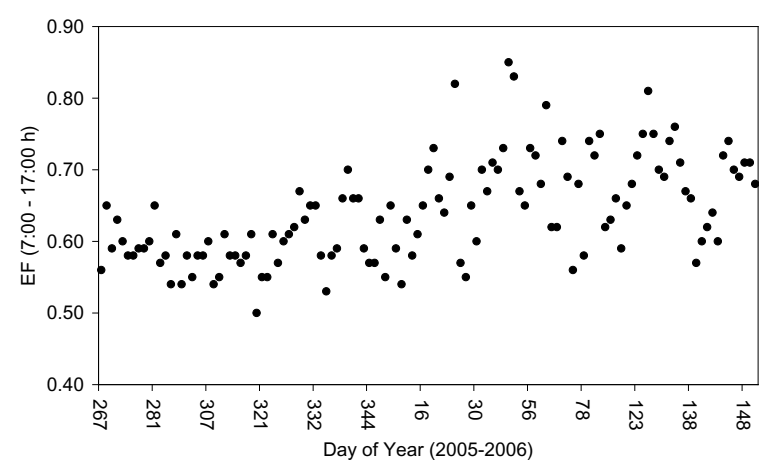

Figure 7 - Behavior of the daily evaporative fraction (EF) during the entire study period (142 days)

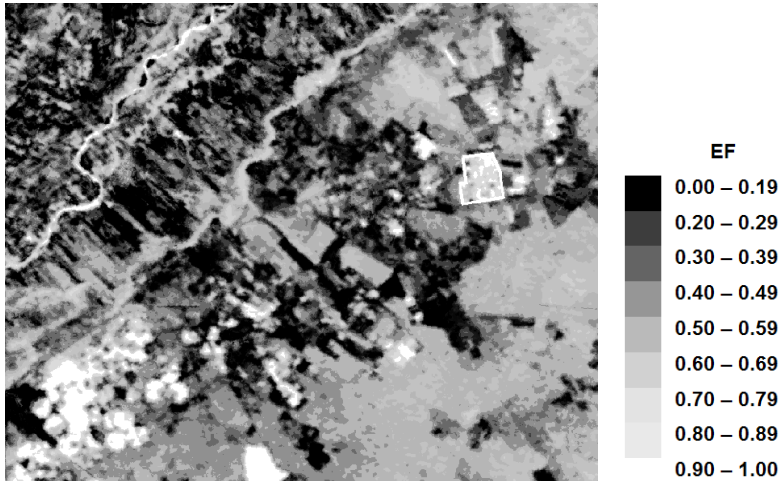

Figure 8 - Spatial distribution of instantaneous evaporative fraction estimated by SEBAL, in 10/24/2005, to semi-arid region of Brazil, with highlight to banana orchard area. 


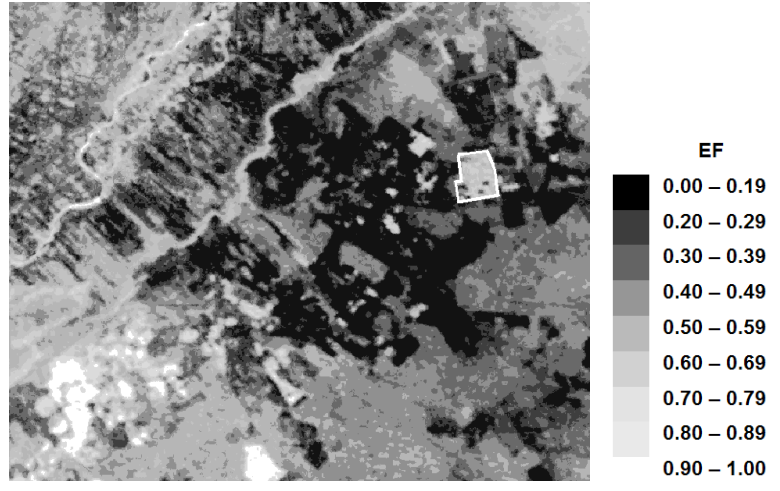

Figure 9 - Spatial distribution of instantaneous evaporative fraction estimated by SEBAL, in $01 / 28 / 2006$, to semi-arid region of Brazil, with highlight to banana orchard area.

results evidenced the agreement between the SEBAL results and measured data and as a sufficiently robust algorithm to provide estimates of the EF to obtain the ET, being used mainly for water management (Teixeira et al., 2009a).

\section{CONCLUSIONS}

This study is aimed to demonstrate the ability of the instantaneous measurements of EF to estimate the average daily EF, and apply the remote sensing algorithm (SEBAL) to estimate the regional distribution of the instantaneous EF in the semi-arid region of Brazil. The evaporative fraction has been found from numerous observations to vary little during the daytime. For the period of study, the analysis of the effect of cloudiness on the stability of EF showed that cloudiness is not related to stability of EF, agreeing with the results found by Farah et al. (2004).

Correlation analysis between the diurnal stability of EF and the meteorological parameters have shown weak correlation on cloudy days, and strong correlation with the vapor pressure deficit (VPD) on cloud free days. Hence, the stability of the diurnal cycle of EF on cloudy free days can be adequately explained by VPD. There is a moderate correlation between morning EF and daily EF and a strong correlation between midday EF and daily EF. These results show the indifference in the remote sensing applications to obtain the EF from satellite that has morning or afternoon overpasses.

Satellite remote sensing offers the possibility to derive regional distributions of land surface heat fluxes and ET over heterogeneous land surfaces in combination with sparse field experimental stations. It has been a promising tool to provide reasonable estimates of the EF to obtain the ET. In some agricultural applications, daily ET is often needed more than instantaneous rates. With remotely sensed surface temperatures, methods to extend instantaneous to daily ET are needed because

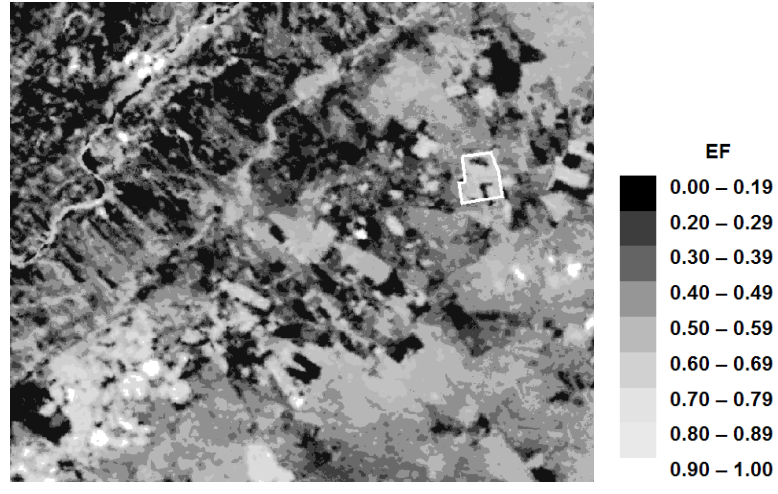

Figure 10 - Spatial distribution of instantaneous evaporative fraction estimated by SEBAL, in 10/24/2005, to semi-arid region of Brazil, with highlight to banana orchard area.

orbiting satellites usually provide coverage only once daily. The EF derived from Landsat-5 TM data were compared with the field measurements and presented absolute percent difference less than $12 \%$, evidencing the agreement between the SEBAL results and measured data, and showing the satellite remote sensing as a promising tool to provide estimates of the EF to obtain the ET.

\section{ACKNOWLEDGEMENTS}

To the Conselho Nacional de Desenvolvimento Científico e Tecnológico (CNPq) for fellowship and financial support. To the Frutacor farm which released cultivated areas for the accomplishment of this experiment. The authors thank the anonymous reviewers whose suggestions were helpful for improving the quality of this paper.

\section{REFERENCES}

ALlEN, R. G., PEREIRA, L. S., RAES, D., SMITH, M. Crop Evapotranspiration: Guidelines for Computing Crop Requirements. Irrigation and Drainage Paper No. 56. FAO, Rome, Italy, 1998, p. 331.

BASTIAANSSEN, W. G. M.; MENENTI, M.; FEDDES, R. A.; HOLTSLAG, A. A. M. A remote sensing surface energy balance algorithm for land (SEBAL) 1. Formulation. Journal of Hydrology, v. 212-213, p.198-212. 1998.

BASTIAANSSEN, W. G. M., MOLDEN, D. J., MAKIN, I. W. Remote sensing for irrigated agriculture: examples from research and possible applications. Agricultural Water Management, v. 46, p. 137-155, 2000.

BRUTSAERT, W., SUGITA, M. Application of self-preservation in the diurnal evolution of the surface energy budget to determine daily evaporation. Journal Geophysical Research, v. 97, p.1837718382, 1992. 
CHÁVEZ, J. L., NEALE, C. M. U., PRUEGER, J. H., KUSTAS, W. P. Daily evapotranspiration estimates from extrapolating instantaneous airborne remote sensing ET values. Irrigation Science, v. 27, p. 67-81, 2008.

COLAIZZI, P. D., EVETT, S. R., HOWELL, T. A., TOLK, J. A. Comparison of Five Models to Scale Daily Evapotranspiration from One-Time-of-Day Measurements. Transactions of the ASABE, v. 49, p.1409-1417, 2006.

COMPAORÉ, H., HENDRICKX, J. M. H., HONG, S., FRIESEN, J., VAN DE GIESEN, N. C., RODGERS, C., SZARZYNSKI, J., VLEK, P. L. G. Evaporation mapping at two scales using optical imagery in the White Volta Basin, Upper East Ghana. Physics and Chemistry of the Earth, v. 33, p. 127-140, 2008.

CRAGO, R. D. Comparison of the evaporative fraction and PriestlyTaylor for the parameterizating daytime evaporation. Water Resources Research, v.32, p.1403-1409, 1996a.

CRAGO, R. D. Conservation and variability of the evaporative fraction during the daytime. Journal of Hydrology, v.180, p.173-194, 1996 b.

CRAGO, R. D., BRUTSAERT, W. Daytime evaporation and the self-preservation of the evaporative fraction and the Bowen ratio. Journal of Hydrology, v.178, p.241-255, 1996.

FARAH, H. O., BASTIAANSSEN, W. G. M., FEDDES, R. A. Evaluation of the temporal variability of the evaporative fraction in a tropical watershed. International Journal of Applied Earth Observation and Geoinformation, v.5, p.129-140, 2004.

FRENCH A. N., SCHMUGGE, T. J., KUSTAS, W. P. Estimating surface fluxes over the SGP site with remotely sensed data. Physics and Chemistry of the Earth, v.25, p.167-172, 2000. GENTINE, P., ENTEKHABI, D., CHEHBOUNI, A., BOULET, G., DUCHEMIN, B. Analysis of evaporative fraction diurnal behavior. Agricultural and Forest Meteorology, v.143, p.13-29, 2007.

GIOLIA, B., MIGLIETTAA, F., MARTINOA, B. D., HUTJESB, R. W. A., DOLMANC, H. A. J., LINDROTHD, A., SCHUMACHERE, M., SANZF, M. J., MANCAG, G., PERESSOTTIH, A., DUMASI, E. J. Comparison between tower and aircraft-based eddy covariance fluxes in five European regions. Agriculture and Forest Meteorology, v.127, p.1-16, 2004.

HALL, F. G., HUEMMRICH, K. F., GOETZ, S. J., SELLERS, P. J., NICKESON, J. E. Satellite remote sensing of the surface energy balance: success, failures and unresolved issues in FIFE. Journal of Geophysical Resources, v.97, p.19061-19089, 1992.

HOEDJES, J. C. B., CHEHBOUNI, A., JACOB, F., EZZAHAR, J., BOULET, G. Deriving daily evapotranspiration from remotely sensed instantaneous evaporative fraction over olive orchard in semi-arid Morocco. Journal of Hydrology, v.354, p.53-64, 2008.

KALTHOFF, N., FIEBIG-WITTMAACK, M., MEIBNER, C., KOHLER, M., URIARTE, M., BISCHOFF-GAUB, I., GONZALES, E. The energy balance evapo-transpiration and nocturnal dew deposition of an arid valley in the Andes. Journal of Arid Environments, v.65, p.420-443, 2006.
KUSTAS, W. P., NORMAN, J. M. Use of remote sensing for evapotranspiration monitoring over land surfaces. Hydrological Science Journal, v.41, p.495-515, 1996.

MELESSE, A. M., NANGIA, V. Estimation of spatially distributed surface energy fluxes using remotely-sensed data for agricultural fields. Hydrological Processes, v.19, p.2653-2670, 2005.

MELESSE, A. M., FRANK, A., NANGIA, V., HANSON, J. Analysis of energy fluxes and land surface parameters in a grassland ecosystem: a remote sensing perspective. International Journal of Remote Sensing, v.29, p.3325-3341, 2008.

NICHOLS, W. E., CUENCA, R. H. Evaluation of the evaporative fraction for the parameterization of the surface energy balance. Water Resources Research, v.29, p.3681-3690, 1993.

ROERINK, G. J., SU, Z., MENENTI, M. A Simple Remote Sensing Algorithm to Estimate the Surface Energy Balance. Physics and Chemistry of the Earth (B), v.25, p.147-157, 2000. SHUTTLEWORTH, W. J., GURNEY, R. J., HSU, A. Y., ORMSBY, J. P. FIFE: the variation in energy partition at surface flux sites. IAHS Publication, v.186, p.67-74, 1989.

SUGITA, M.; BRUTSAERT, W. Daily evaporation over a region from lower boundary layer profiles measured with radiosondes. Water Resources Research, v. 27, p. 747-752, 1991.

TANAKA, H., HIYAMA, T., KOBAYASHI, N., YABUKI, H., ISHII, Y., DESYATKIN, R. V., MAXIMOV, T. C., OHTA, T. Energy balance and its closure over a young larch forest in eastern Siberia. Agricultural and Forest Meteorology, v.148, p.1954-1967, 2008.

TASUMI, M., TREZZA, R., ALLEN, R. G., WRIGHT, J. L. Operational aspects of satellite-based energy balance models for irrigated crops in the semi-arid U.S. Irrigation and Drainage Systems, v.19, p.355-376, 2005.

TEIXEIRA, A. H. C.; BASTIAANSSEN, W. G. M.; AHMAD, M. D.; BOS, M. G. Reviewing SEBAL input parameters for assessing evapotranspiration and water productivity for the Low-Middle São Francisco River basin, Brazil Part A: Calibration and validation. Agricultural and Forest Meteorology, v. 149, p. 462-476, 2009a.

TEIXEIRA, A. H. C.; BASTIAANSSEN, W. G. M.; AHMAD, M. D.; BOS, M. G. Reviewing SEBAL input parameters for assessing evapotranspiration and water productivity for the Low-Middle São Francisco River basin, Brazil Part B: Application to the regional scale. Agricultural and Forest Meteorology, v. 149, p. 477-490, 2009b.

TWINE, T. E., KUSTAS, W. P., NORMAN, J. M., COOK, D. R., HOUSER, P. R., MEYERS, T. P., PRUEGER, J. H., STARKS, P. J., WESELY, M. L. Correcting eddy-covariance flux underestimates over grassland. Agricultural and Forest Meteorology, v.103, p.279-3000, 2000. 